\title{
PERANAN GURU PENDIDIKAN AGAMA ISLAM DALAM MEMBINA AKHLAQUL KARIMAH SISWA
}

Oleh

Suprihatin

Sekolah Tinggi Agama Islam Ma'arif Jambi suprihatin.atin.priha@gmail.com

\begin{abstract}
The main function of the teacher is as a role model for his students. That is, that a teacher must be an example and role model, arouse learning motivation and encourage students from behind. The teacher is a human figure who occupies the most important position in education. Teachers as central in the world of education. Exemplary is one of the methods of education that has a big influence on the success of the teaching and learning process. The Islamic system in improving children is based on two basic principles, namely teaching and habituation. The purpose of teaching (Talqin) here is to approach theoretical aspects in efforts to improve children.
\end{abstract}

Keywords. Role, teacher, fostering, morals

\begin{abstract}
Abstrak
Fungsi utama guru adalah sebagai teladan bagi anak didiknya. Artinya, bahwa seorang guru harus menjadi contoh dan teladan, membangkitkan motivasi belajar serta mendorong siswa dari belakang. Guru adalah figure manusia yang menempati posisi paling penting dalam pendidikan. Guru sebagai sentral dalam dunia pendidikan. Keteladanan merupakan salah satu metode pendidikan yang besar pengaruhnya terhadap keberhasilan proses belajar mengajar. Sistem Islam dalam memperbaiki anak adalah bersandar pada dua dasar pokok yaitu pengajaran dan pembiasaan. Maksud pengajaran (Talqin) di sini ialah pendekatan aspek teoritis dalam upaya memperbaiki anak.
\end{abstract}

Kata kunci. Peran, guru, membina, akhlak 


\section{A. PENDAHULUAN}

Pembangunan sebuah negara yang maju dan berkembang di dalamnya dibutuhkan generasi muda yang memiliki kecerdasan dan kemampuan yang tinggi. Salah satu upaya untuk mewujudkannya adalah melalui pendidikan. Era globalisasi yang semakin maju dan serba canggih seperti sekarang ini, mempengaruhi suasana lingkungan.

Perkembangan globalisasi memberikan pengaruh yang positif maupun negatif bagi masyarakat. Perkembangan tekhnologi mempunyai dampak yang besar terhadap kehidupan kerohanian dan perubahan-perubahan nilai. Dalam kemajuan globalisasi ini jika tidak pandai memanfaatkan kemajuan tersebut, maka kehancuranlah yang akan di dapati. Kenyataan pada saat ini, gejala merosotnya moral kian tak terbendung, fenomena maraknya perilaku menyimpang dikalangan siswa, aksiaksi kekerasan, tawuran antar pelajar, pornografi, pemerkosaan, seks bebas, penggunaan obat-obat terlarang, serta banyak lagi yang lainnya, yang membuktikan bahwa kasus degradasi moral dan dekadensi nilai-nilai religious semakin meningkat.

Melihat fenomena sosial tersebut, pendidikan agama Islam diharapkan dapat mencegah timbulnya berbagai kasus yang memprihatinkan, serta mampu mengatasi dan mengantisipasi berbagai kasus moral tersebut. Salah satu upaya untuk mewujudkannya adalah melalui pendidikan. Pendidikan merupakan modal yang penting dan utama untuk membentuk generasi muda yang berkualitas. Sebagai agen peradaban dan perubahan social, pendidikan Islam berada dalam atmosfir modernisasi dan globalisasi dituntut untuk mampu memainkan perannya secara dinamis dan proaktif. ${ }^{1}$

Sehubungan dengan hal tersebut, hal yang paling penting untuk ditanamkan pada setiap siswa adalah menanamkan dan membina akhlaqul karimah sedini mungkin. Akhlak merupakan salah satu bagian yang sangat urgen dari perincian kesempurnaan tujuan pendidikan Islam. Oleh sebab itu, pendidikan akhlak merupakan salah satu pondasi yang penting dalam membentuk insan yang berakhlak mulia guna menciptakan manusia yang bertaqwa dan menjadi seorang muslim yang sejati. Dengan pelaksanaan pendidikan akhlak tersebut, diharapkan setiap muslim mampu menerapkannya dalam kehidupan sehari-hari. Pendidikan akhlak dapat mengatarkan pada jenjang kemuliaan akhlak karena dengan pendidikan akhlak tersebut, manusia menjadi semakin mengerti akan kedudukan dan tugasnya sebagai hamba dan khalifah di bumi.

Guru adalah figure manusia yang menempati posisi paling penting dalam pendidikan. Guru sebagai sentral dalam dunia pendidikan, khususnya dalam proses belajar mengajar. Sehubungan dengan ini, setiap guru sangat diharapkan memiliki karakteristik (ciri khas) kepribadian

${ }^{1}$ Sukarji \& Umiarso, Manajemen dalam Pendidikan Islam (Jakarta: Mitra Wacana Media, 2014), hal. 106. 
yang ideal sesuai dengan persyaratan yang bersifat psikologis-pedagogis. ${ }^{2}$

Guru memiliki peran ganda, yakni sebagai pengajar dan sebagai pendidik. Dalam rangka mengembangkan peran gandanya, maka guru memiliki persyaratan kepribadian sebagai guru. Persyaratan kepribadian tersebut yaitu: suka bekerja keras, demokratis, penyayang, menghargai kepribadian peserta didik, sabar, memiliki pengetahuan, ketrampilan dan pengalaman yang bermacam-macam, perawakan menyenangkan dan berkelakuan baik, adil dan tidak memihak, toleransi, mantap dan stabil, ada perhatian terhadap persoalan peserta didik, lincah, mampu memuji, perbuatan baik dan menghargai peserta didik, cukup dalam pengajaran, dan mampu memimpin secara baik. ${ }^{3}$

Demi tercapainya tujuan tersebut, maka guru memegang peranan penting. Guru disekolah tidak hanya sekedar mentransfer sejumlah ilmu pengetahuan kepada murid-muridnya, tetapi lebih dari itu, terutama dalam membina sikap dan ketrampilan murid. Sebab pendidikan agama Islam sangat menentukan dalam hal pembinaan sikap siswa, karena di dalamnya mengenai aqidah dan akhlaqul karimah.

\footnotetext{
${ }^{2}$ Muhibbin Syah, Psikologi Pendidikan suatu Pendekatan Baru (Bandung: Remaja Rosdakarya, 1996), hal. 221.

3 Ahmad Rohani dan Abu Ahmad, Pengelolaan Pengajaran (Jakarta: Rineka Cipta, 1996), hal. 110.
}

\section{B. PEMBAHASAN}

\section{Peranan Guru Pendidikan Agama Islam}

Keberadaan guru dalam pendidikan sangat penting, artinya ia mempunyai tugas dan tanggung jawab dalam memajukan dan mencerdaskan masyarakat suatu bangsa. Untuk itu, seorang guru harus memenuhi beberapa persyaratan dan ketentuan demi terciptanya tujuan pendidikan.

Seperti yang tertera Dalam UU No. 14 tahun 2005 Tentang Guru dan Dosen menegaskan bahwa "Dalam melaksanakan tugas keprofesionalan, guru berkewajiban merencanakan pembelajaran, melaksanakan proses pembelajaran yang bermutu, serta menilai dan mengevalusai hasil pembelajaran serta meningkatkan dan mengembangkan kualifikasi akademik dan kompetensi secara berkelanjutan sejalan dengan perkembangan ilmu pengetahuan, teknologi, dan seni". Maka jelaslah proses pendidikan tidak akan terlaksana dengan baik jika kewajiban guru diabaikan.

Guru yang professional adalah seorang pendidik yang dituntut arif dan bijaksana. Karena hanya guru yang professional lah yang bisa melahirkan generasi yang cerdas. Keinginan untuk menjadi professional, hendaknya tumbuh dari dalam diri seorang guru yang bersangkutan. Pada prinsipnya berbicara mutu pendidikan, secara kompetensi akan bermuara kepada sang guru karena dialah yang bertatap muka dengan obyek pendidikan itu sendiri.

${ }^{4}$ UU No. 14 Tahun 2005 Tentang Guru dan Dosen Bab IV Pasal 20 
Menurut pendapat Asef Umar Fakhruddin, guru dijabarkan sebagai sebuah pekerjaan profesional yang membutuhkan kemampuan khusus hasil proses pendidikan yang dilaksanakan oleh lembaga pendidikan keguruan. ${ }^{5}$ Sedangkan menurut pendapat Imam Musbikin, seorang guru adalah pendidik yaitu orang yang memikul tanggung jawab untuk membimbing. ${ }^{6}$

a. Tugas dan Peran Guru

Seorang guru memiliki banyak tugas, baik yang terikat oleh dinas maupun di luar dinas dalam bentuk pengabdian, menurut Asef Umar Fakhruddin dibagi menjadi (3) tiga kelompok, yaitu:

1. Tugas sebagai profesi meliputi mendidik dalam pengembangan nilai-nilai kehidupan, melatih dalam pengembangan keterampilan, dan mengajar dalam pengembangan ilmu pengetahuan dan teknologi kepada siswanya.

2. Tugas dalam bidang kemanusiaan, guru dituntut untuk dapat menjadikan dirinya sebagai orang tua kedua di sekolah, dituntut untuk mampu menarik simpati sehingga dapat menjadi idola para siswanya.

3. Tugas dalam bidang kemasyarakatan meliputi hal mendidik dan mengajar masyarakat untuk menjadi warga

${ }^{5}$ Asef Umar Fakhruddin, Menjadi Guru Favorit (Yogyakarta: DIVA Press, 2009), hal. 43.

6 Imam Musbikin, Guru Yang Menakjubkan, (Yogyakarta: Buku Biru. 2010), hal. 25. negara Indonesia yang bermoral Pancasila, serta mencerdaskan bangsa Indonesia. ${ }^{7}$

Sedangkan menurut pendapat Imam Musbikin, peranan guru sebagai pendidik meliputi:

1. Guru sebagai korektor, harus dapat membedakan nilai yang baik dan yang buruk.

2. Guru sebagai inspirator, harus dapat memberikan ilham yang baik bagi kemajuan anak didiknya.

3. Guru sebagai informator, guru harus dapat memberikan informasi pengembangan ilmu pengetahuan dan teknologi.

4. Guru sebagai organisator, harus memiliki kegiatan pengelolaan akademik, menyusun tata tertib sekolah, menyusun kalender akademik, dan sebagainya.

5. Guru sebagai motivator, harus dapat mendorong semangat anak didiknya agar aktif dalam belajar.

6. Guru sebagai inisiator, harus dapat mencetuskan ide-ide kemajuan dalam pendidikan dan pengajaran.

7. Guru sebagai fasilitator, harus dapat menyediakan fasilitas yang memadai untuk memudahkan terlaksananya kegiatan belajar anak didiknya, menciptakan lingkungan belajar yang menyenangkan.

8. Guru sebagai pembimbing, harus dapat membimbing anak didiknya yang masih anak-anak menjadi manusia dewasa sehingga cakap dan mandiri.

\footnotetext{
${ }^{7}$ Asef Umar Fakhruddin, Op., Cit., hal. 74-76.
} 
9. Guru sebagai demonstrator, harus dapat memperagakan apa yang diajarkan secara diktatis, sehingga apa yang ia inginkan sejalan dengan pemahaman anak didiknya, serta tercapainya tujuan pengajaran secara efektif dan efisien.

10. Guru sebagai pengelola kelas, harus dapat membuat anak didiknya betah tinggal di kelas dengan motivasi yang tinggi untuk senantiasa belajar di dalamnya.

11. Guru sebagai mediator, harus memiliki pengetahuan dan pemahaman tentang media pendidikan baik jenis dan bentuknya, baik media material maupun non material.

12. Guru sebagai supervisor, harus dapat membantu, memperbaiki, dan menilai secara kritis terhadap proses pengajaran.

13. Guru sebagai elevator, dituntut untuk dapat menjadi elevator yang baik dan jujur dengan memberikan penilaian yang menyangkut intrinsik maupun ekstrinsik. ${ }^{8}$

b. Kompetensi Guru

Menurut Peraturan Menteri Pendidikan Nasional Republik Indonesia Nomor 16 Tahun 2007 Tentang Standar Kualifikasi Akademik dan Kompetensi Guru, adapun macammacam kompetensi yang harus dimiliki oleh tenaga guru antara lain yaitu:

\section{Kompetensi Pedagogik}

Kompetensi pedagogik meliputi pemahaman guru terhadap peserta didik, perancangan dan pelaksanaan pembelajaran, evaluasi hasil belajar,

\footnotetext{
${ }^{8}$ Imam Musbikin, Op., Cit, hal. 55-64.
}

dan pengembangan peserta didik untuk mengaktualisasikan berbagai potensi yang dimilikinya. Secara rinci setiap sub kompetensi dijabarkan menjadi indikator esensial sebagai berikut:

1) Memahami peserta didik secara mendalam memiliki indikator esensial: memahami peserta didik dengan memanfaatkan prinsipprinsip perkembangan kognitif; memahami peserta didik dengan memanfaatkan prinsip-prinsip kepribadian; dan mengidentifikasi bekal ajar awal peserta didik.

2) Merancang pembelajaran, termasuk memahami landasan pendidikan untuk kepentingan pembelajaran memiliki indikator esensial: memahami landasan kependidikan; menerapkan teori belajar dan pembelajaran; menentukan strategi pembelajaran berdasarkan karakteristik peserta didik, kompetensi yang ingin dicapai, dan materi ajar; serta menyusun rancangan pembelajaran berdasarkan strategi yang dipilih.

3) Melaksanakan pembelajaran memiliki indikator esensial: menata latar (setting) pembelajaran; dan melaksanakan pembelajaran yang kondusif.

4) Merancang dan melaksanakan evaluasi pembelajaran memiliki indikator esensial: merancang dan melaksanakan evaluasi (assessment) proses dan hasil belajar secara berkesinambungan dengan berbagai metode; menganalisis hasil evaluasi proses dan hasil belajar untuk menentukan tingkat ketuntasan belajar (mastery 
learning); dan memanfaatkan hasil penilaian pembelajaran untuk perbaikan kualitas program pembelajaran secara umum.

5) Mengembangkan peserta didik untuk mengaktualisasikan berbagai potensinya, memiliki indikator esensial: memfasilitasi peserta didik untuk pengembangan berbagai potensi akademik; dan memfasilitasi peserta didik untuk mengembangkan berbagai potensi nonakademik.

2. Kompetensi Kepribadian

Kompetensi

kepribadian

merupakan kemampuan personal yang mencerminkan kepribadian yang mantap, stabil, dewasa, arif, dan berwibawa, menjadi teladan bagi peserta didik, dan berakhlak mulia. Secara rinci subkompetensi tersebut dapat dijabarkan sebagai berikut:

1) Kepribadian yang mantap dan stabil memiliki indikator esensial: bertindak sesuai dengan norma hukum; bertindak sesuai dengan norma sosial; bangga sebagai guru; dan memiliki konsistensi dalam bertindak sesuai dengan norma.

2) Kepribadian yang dewasa memiliki indikator esensial: menampilkan kemandirian dalam bertindak sebagai pendidik dan memiliki etos kerja sebagai guru.

3) Kepribadian yang arif memiliki indikator esensial: menampilkan tindakan yang didasarkan pada kemanfaatan peserta didik, sekolah, dan masyarakat serta menunjukkan keterbukaan dalam berpikir dan bertindak.

4) Kepribadian yang berwibawa memiliki indikator esensial: memiliki perilaku yang berpengaruh positif terhadap peserta didik dan memiliki perilaku yang disegani.

5) Akhlak mulia dan dapat menjadi teladan memiliki indikator esensial: bertindak sesuai dengan norma religius (iman dan taqwa, jujur, ikhlas, suka menolong), dan memiliki perilaku yang diteladani peserta didik.

3. Kompetensi Sosial

Kompetensi sosial merupakan kemampuan guru untuk berkomunikasi dan bergaul secara efektif dengan peserta didik, sesama pendidik, tenaga kependidikan, orang tua/wali peserta didik, dan masyarakat sekitar. Kompetensi ini memiliki subkompetensi dengan indikator esensial sebagai berikut:

1) Mampu berkomunikasi dan bergaul secara efektif dengan peserta didik memiliki indikator esensial: berkomunikasi secara efektif dengan peserta didik.

2) Mampu berkomunikasi dan bergaul secara efektif dengan sesama pendidik dan tenaga kependidikan.

3) Mampu berkomunikasi dan bergaul secara efektif dengan orang tua/wali peserta didik dan masyarakat sekitar.

4. Kompetensi Profesional

Kompetensi profesional
merupakan penguasaan materi
pembelajaran secara luas dan
mendalam, yang mencakup penguasaan
materi kurikulum mata pelajaran di
sekolah dan substansi keilmuan yang


menaungi materinya, serta penguasaan terhadap stuktur dan metodologi keilmuannya. Setiap subkompetensi tersebut memiliki indikator esensial sebagai berikut:

1) Menguasai substansi keilmuan yang terkait dengan bidang studi memiliki indikator esensial: memahami materi ajar yang ada dalam kurikulum sekolah; memahami struktur, konsep dan metode keilmuan yang menaungi atau koheren dengan materi ajar; memahami hubungan konsep antar mata pelajaran terkait; dan menerapkan konsep-konsep keilmuan dalam kehidupan seharihari.

2) Menguasai struktur dan metode keilmuan memiliki indikator esensial menguasai langkahlangkah penelitian dan kajian kritis untuk memperdalam pengetahuan/materi bidang studi.

Keempat kompetensi tersebut di atas bersifat holistik dan integratif dalam kinerja guru. Oleh karena itu, secara utuh sosok kompetensi guru meliputi (a) pengenalan peserta didik secara mendalam; (b) penguasaan bidang studi baik disiplin ilmu (disciplinary content) maupun bahan ajar dalam kurikulum sekolah (c) penyelenggaraan pembelajaran yang mendidik yang meliputi perencanaan dan pelaksanaan pembelajaran, evaluasi proses dan hasil belajar, serta tindak lanjut untuk perbaikan dan pengayaan; dan (d) pengembangan kepribadian dan profesionalitas secara berkelanjutan. Guru yang memiliki kompetensi akan dapat melaksanakan tugasnya secara professional. $^{9}$

c. Prinsip Profesionalitas Guru

Prinsip profesionalitas guru dalam Pasal 7 ayat (1) UndangUndang Nomor 14 Tahun 2005 tentang Guru dan Dosen yaitu sebagai berikut:

1) Memiliki bakat, minat, panggilan jiwa, serta idealisme

2) Memiliki komitmen untuk meningkatkan mutu pendidikan, keimanan, ketakwaan, dan akhlak yang mulia

3) Memiliki kualifikasi akademik atau latar belakang pendidikan sesuai dengan bidang tugas nya

4) Memiliki kompetensi yang diperlukan sesuai dengan bidang tugasnya;

5) memiliki tanggungjawab dalam pelaksanaan tugas keprofesionalan

6) memperoleh penghasilan yang ditentukan sesuai dengan prestasi kerja

7) Memiliki kesempatan untuk mengembangkan keprofesionalannya secara berkelanjutan dengan belajar sepanjang hayat

8) Memiliki jaminan perlindungan hukumdalam melaksanakan tugas keprofesionalan

9) Memiliki organisasi profesi yang mempunyai kewenangan mengatur

9 Ngainun Naim, Menjadi Guru Inspiratif: Membudayakan dan Mengubah Jalan Hidup Siswa (Yogyakarta: Pustaka Pelajar. 2009), hal. 60. 
hal-hal yang berkaitan dengan tugas keprofesionalan guru. ${ }^{10}$

Mukhtar dan Iskandar
mengemukakan ada tiga dasar
kompetensi yang harus dimiliki guru yaitu; kompetensi pengetahuan dan pengalaman, kompetensi moral, kompetensi keterampilan mengajar. Secara umum ada sepuluh kompetensi dasar yang diperlukan seorang guru dalam menjalankan tugas mengajar, yaitu menguasai bahan ajar, mampu mengelolah sumber belajar mengajar, mengelola kelas, menggunakan media/sumber, menguasai landasan pendidikan, mengelolah interaksi belajar/mengajar/metode mengajar, menilai prestasi belajar siswa untuk kepentingan pengajaran, mengenal dan menyelenggarakan administrasi sekolah, mengenal fungsi dan program bimbingan dan penyuluhan di sekolah, memahami prinsip-prinsip dan menafsirkan hasil penelitian guna keperluan pengajaran. ${ }^{11}$

M. Athiyah Al-Abrasyi berpendapat, guru dalam Islam harus memiliki kompetensi/kemampuan sebagai berikut:

1. Zuhud

Seorang guru menduduki tempat yang tinggi dan suci, maka ia harus tahu kewajiban yang sesuai dengan posisinya sebagai guru, ia haruslah seorang yang benar-benar zuhud. Ia mengajar dengan maksud mencari keridhaan Ilahi, bukan

${ }^{10}$ https://eprints.uns.ac.id/263/1/1703123 11201011381.pdf.Diakses Pada 11 Januari 2018.

${ }^{11}$ Mukhtar dan Iskandar, Orientasi Baru Supervisi Pendidikan (Jakarta: Gaung Persada, 2009), hal. 125-126. karena mencari upah, gaji atau uang balas jasa, artinya ia tidak menghendaki dengan mengajar itu selain mencari ridho Allah Swt, dan menyebarkan ilmu pengetahuan.

\section{Kebersihan Guru}

Seorang guru harus bersih tubuhnya, jauh dari dosa dan kesalahan, bersih jiwa, terhindar dari dosa besar, sifat ria' (mencari nama), dengki, permusuhan, perselisihan dan terhindar dari sifat-sifat tercela.

3. Ikhlas

Keikhlasan dan kejujuran seorang guru di dalam pekerjaannya merupakan jalan terbaik kearah suksesnya di dalam tugas dan sukses murid-muridnya. Termasuk ikhlas ialah seorang guru yang sesuai kata dengan perbuatan, melakukan apa yang ia ucapkan, dan tidak malu-malu mengatakan: aku tidak tahu, bila ada yang tidak diketahuinya.

4. Pemaaf

Seorang guru harus bersifat pemaaf terhadap muridnya, ia sanggup menahan diri, menahan kemarahan, lapang hati, banyak sabar dan jangan marah karena sebab-sebab yang kecil.

5. Seorang guru merupakan seorang bapak/ibu sebelum ia seorang guru Seorang guru harus mencintai murid-muridnya seperti cintanya terhadap anak-anaknya sendiri dan memikirkan keadaan mereka seperti ia memikirkan anakanaknya sendiri. 
6. Seorang guru harus mengetahui tabiat murid

Guru harus mengetahui tabiat pembawaan, adat kebiasaan, rasa dan pemikiran murid agar ia tidak kesasar di dalam mendidik anakanak.

7. Seorang guru harus menguasai mata pelajaran

Seorang guru harus sanggup menguasai mata pelajaran yang diberikannya, serta memperdalam pengetahuannya tentang itu sehingga janganlah pelajaran itu bersifat dangkal, tidak melepaskan dahaga dan tidak mengenyangkan. ${ }^{12}$

Zakiah Daradjat menuturkan budi pekerti yang baik (akhlaqul karimah) sangat penting untuk dimiliki oleh seorang guru (pendidik). Sebab, semua sifat dan akhlak yang dimiliki seorang guru akan senantiasa ditiru oleh anak didiknya. Yang dimaksud akhlak baik yang harus dimiliki oleh guru dalam konteks pendidikan Islam ialah akhlak yang sesuai dengan tuntunan agama Islam, seperti yang dicontohkan oleh pendidik utama Nabi Muhammad Saw dan para utusan Allah yang lainnya. Diantara akhlak guru tersebut adalah: ${ }^{13}$

a. Mencintai jabatannya sebagai guru

Tidak semua orang yang menjadi guru karena panggilan jiwa.

${ }^{12}$ M. Athiyah Al-Abrasyi, Dasar Dasar

Pokok Pendidikan Islam (Jakarta: Bulan Bintang, 1993), hal. 137-140.

${ }^{13}$ Zakiah Daradjat, Ilmu Pendidikan Islam (Jakarta: Bumi Aksara, 1992). hal. 44.
Diantara mereka ada yang menjadi guru karena dorongan ekonomi, dorongan teman atau orang tua, dan lainnya. Dan bagaimanapun seorang guru harus mencintai profesinya. Karena dengan kecintaannya tersebut seorang guru dapat menghayati serta tulus dalam menjalankan tugas sebagai guru.

b. Bersikap adil kepada semua muridnya

Peserta didik sangat tajam pandangannya terhadap perlakuan yang tidak adil. Guru kerapkali pilih kasih atau tidak adil kepada semua muridnya. Contohnya, lebih memperhatikan salah satu muridnya yang pintar dan membiarkan yang lainnya.Hal itu jelas tidak baik, oleh karena itu seorang guru harus bersikap adil dalam kondisi apapun.

c. Berlaku sabar dan tenang

Di sekolah guru kerapkali merasakan kekecewaan karena murid kurang mengerti apa yang diajarkannya serta menemui beberapa masalah dalam proses pembelajaran. Oleh karena itu, guru harus bersikap tabah, sabar sambil mengkaji masalahnya dengan tenang.

d. Guru harus berwibawa

Anak-anak ribut dan berbuat sekehendaknya, lalu guru merasa jengkel, dan meluapkan emosinya dengan marah bahkan memukul anak didik. Guru semacam ini adalah gambaran guru yang tidak berwibawa. Sebaliknya, guru yang berwibawa ialah guru yang mampu menguasai anak didiknya dalam 
keadaan apapun dengan cara yang baik. Inilah guru yang berwibawa.

e. Guru harus gembira Guru yang gembira biasanya tidak lekas kecewa kepada anak didiknya yang sulit menerima materi yang diajarkan.Ia mengerti bahwa anak didiknya tidak bodoh, akan tetapi belum tahu. Dengan gembira, seorang guru harus menerangkan pelajaran sampai anak didiknya memahami materinya.

f. Guru harus bersifat manusiawi Guru adalah manusia yang tak lepas dari kekurangan dan cacat. Guru bukan manusia sempurna. Oleh karena itu, guru harus bisa mengetahui kekurangannya serta mampu memperbaikinya. Dengan demikian, guru bisa memahami sifat anak didiknya yang juga tak terlepas dari kesalahan.Oleh karena itu, guru harus bisa memperlakukan anak didiknya dengan adil dan manusiawi. Meskipun dengan memberi hukuman, tetapi yang terpenting adalah hukuman itu tidak sampai melanggar norma pendidikan yang berlaku.

g. Bekerja sama dengan guru lain Pertalian dan kerja sama yang erat antara guru-guru lebih berharga daripada fasilitas penunjang pendidikan yang memadai. Sebab apabila guru saling bertentangan, anak didik akan merasa bingung dengan keadaan tersebut. Oleh karena itu, peran guru dalam menjaga keharmonisan terhadap guru yang lain serta kepada semua jajaran yang ada di sekolah sangatlah penting untuk tetap dijaga kebaikannya.

h. Bekerja sama dengan masyarakat Guru harus mempunyai pandangan yang luas. Ia harus bergaul dengan segala masyarakat dan secara aktif berperan serta dalam masyarakat supaya sekolah menjadi dikenal baik dan tidak di kucilkan oleh masyarakat.

\section{Pembinaan Akhlaqul Karimah Siswa}

Objek kajian akhlak adalah tingkah laku manusia dalam rangka menetapkan nilainya baik atau buruk. Kata akhlaq" berasal dari bahasa arab, yaitu jamak dari kata "khuluqun" yang menurut bahasa berarti budi pekerti, perangai, tingkah laku atau tabiat, tata krama, sopan santun, adab, dan tindakan. Kata akhlak juga berasal dari kata "khalaqa" atau "khalqun", artinya kejadian, serta erat hubungannya dengan "khaliq", artinya menciptakan, tindakan atau perbuatan, sebagaimana terdapat kata, "al-khaliq", artinya pencipta dan "makhluqun", artinya yang diciptakan. ${ }^{14}$

Menurut Imam al-Ghozali ${ }^{15}$ "Akhlak adalah suatu sifat yang tertanam dalam jiwa yang menimbulkan perbuatan-perbuatan dengan gampang dan mudah, tanpa memerlukan pemikiran dan

${ }^{14}$ Beni Ahmad Saebani \& Abdul Hamid, Ilmu Akhlak (Bandung: CV Pustaka Setia, 2010), hal. 13.

15 Abu Hamid Muhammad al-Ghazali, Ihya Ulum ad-Din (Beirut: Dar al-Fikr, 1989), Jilid III, hal 58. 
pertimbangan". Abdul Karim Zaidan ${ }^{16}$ "Akhlak adalah nilai-nilai dan sifatsifat yang tertanam dalam jiwa, yang dengan sorotan dan timbangannya seseorang dapat menilai perbuatannya baik atau buruk, untuk kemudian memilih malakukan atau meninggalkannya". Menurut M Abdullah Darraz akhlak adalah sesuatu kekuatan dalam kehendak yang mantap, kekuatan dalam kehendak mana kombinasi membawa kecenderungan pada pemilihan pihak yang benar (akhlak yang baik) atau pihak yang jahat (akhlak yang jahat). ${ }^{17}$ Akhlak dalam pengertian umum adalah sebuah sistem yang lengkap yang terdiri dari karakteristik-karakteristik akal atau tingkah laku yang membuat orang menjadi istimewa.

Rasulullah Saw merupakan bapak atau tokoh pendiri akhlak mulia di dunia ini. Keteladanan nabi telah Allah abadikan dalam Al-Qur'an yang berbunyi:

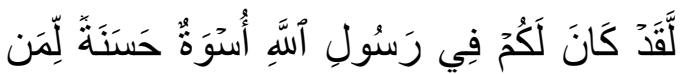

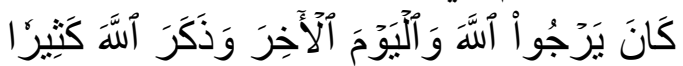

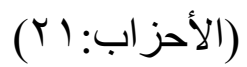

Artinya:

Sesungguhnya telah ada pada (diri) Rasulullah itu suri teladan yang baik bagimu (yaitu) bagi orang yang mengharap (rahmat) Allah dan (kedatangan) hari kiamat dan dia

16 Abdul Karim Zaidan, Ushul adDa'wah (Bagdad: Jam'iyyah al-Amani, 1976), hal.75.

17 Erwin Yuda Prahara, Materi Pendidikan Agama Islam (Ponorogo: STAIN Ponorogo Press, 2009), hal. 182. banyak menyebut Allah (QS Al-Ahzab: 21). ${ }^{18}$

Ayat ini adalah sebagai pengakuan Allah Swt bahwa pada Rasulullah Saw sudah terbukti ada uswatun hasanah padanya dan barang siapa yang mengikutinya sudah pasti akan terselamat di dunia dan akhirat. ${ }^{19}$ Muhammad adalah sebagai satusatunya manusia yang telah melahirkan sebuah doktrin tentang bagaimana manusia seharusnya bertindak baik dengan pencipta maupun makhluk ciptaanNya. Doktrin ini disebut dengan al-akhlaq al-karimah. Rasulullah Saw merupakan seorang manusia yang pertama sekali mencetuskan gagasan tentang akhlak dan seluruh perbuatan dan perkataannya dapat dijadikan teladan bagi manusia. ${ }^{20}$ Semua akhlak yang diajarkan Rasulullah Saw tak lain adalah moralitas bermuara pada Alqur'an. ${ }^{21}$ Dengan demikian, jelas bahwa Rasulullah Saw. Memiliki tinggkah laku yang mulia, beliau selalu bertindak sesuai dengan petunjuk yang berada dalam Alqur'an.

Rasulullah Saw diberi tugas untuk menyampaikan agama Allah kepada manusia, agar manusia mempunyai akhlak yang agung. ${ }^{22}$ Beliau bersabda:

18 Anonim, Al-Qur'an Terjemah (Jakarta: Akbar As-Samad, 2014), hal. 420. QS Al-Ahzab (33) ayat 21.

19 Muhammad Abdurrahman, Akhlak: Menjadi Seorang Muslim Berkhlak Mulia (Jakarta: Rajawali Press, 2016), hal. 97.

${ }^{20}$ Ibid., hal. 1.

${ }^{21}$ FKI LIM, Gerbang Pesantren: Pengantar Memahami Ajaran Ahlussunnah wal Jama'ah (Kediri: Bidang Penelitian dan Pengembangan LIM PP Lirboyo, 2010), hal. 7.

22 Qody Iyad Ibn Musa Al Yahsubi, Keagungan Kekasih Allah Muhammad Saw 
عن أبي هريرة رضي الله عنه أن رسو الله


الْأَخْلَقَ (رو اه البخاري)

Artinya: "Sesungguhnya aku diutus untuk menyempurnakan akhlak mulia". ${ }^{23}$

Hadits ini menggambarkan tugas Rasulullah Saw sebagai seorang yang berakhlak agung. Hadits ini memperkuat alasan dengan menyatakan bahwa pahala yang tidak putusputusnya itu diperoleh Rasulullah Saw sebagai hasil akhlak yang agung, yang merupakan akhlak yang dimilikinya. Pernyataan bahwa Muhammad mempunyai akhlak yang agung merupakan pujian Allah Swt kepada beliau, yang jarang diberikanNya kepada hamba-hambaNya yang lain.

b. Pokok Keutamaan Akhlak

Menurut pemikir Islam klasik yang membahas tentang akhlak secara intens (seperti Ibnu Miskawaih dan AlGhozali) ada empat pokok keutamaan akhlak yang baik:

\section{Al-Hikmah atau kebijaksanaan}

Kebijaksanaan adalah keutamaan jiwa rasional yang mengetahui segala maujud, baik hal-hal yang bersifat ketuhanan maupun halhal yang bersifat kemanusiaan. Pengetahuan ini membuahkan hasil dalam bentuk pengetahuan rasional yang mampu memberikan keputusan antara yang wajib dilaksanakan dengan wajib ditinggalkan. Ibnu Miskawaih mengatakan bahwa kebijaksanaan adalah pertegasan antara kelancangan

(Jakarta: PT.Raja Grafindo Persada, 2002), hal. 82.

رواه البخاري في "الأدب المفرد" رقم (YVY ) dan kedunguan. Yang dimaksud kelancangan adalah penggunaan daya pikir yang tidak tepat, sedangkan kedunguan ialah membekukan menyampingkan daya pikir tersebut walaupun sebetulnya mempunyai kemampuan. Dengan demikian, yang menjadi tekanan di sini adalah bukanlah pada sisi kualitas daya pikirnya, melainkan pada sisi kemauan untuk menggunakannya. Menurut Ibnu Miskawaih ada tujuh keutamaan yang merupakan bahagian dari al-hikmah, yaitu: ketajaman intelegensi, kuat ingatan, rasionalitas, tangkas, jernih ingatan, jernih pikiran, dan mudah dalam belajar.

Sedangkan al-Ghazali, juga memberikan pengertian yang hampir sama dengan Ibnu Miskawaih. Menurutnya al-hikmah merupakan keutamaan jiwa rasional yang memelihara jiwa sahwiyyat dan jiwa alghadabiyyat yang memungkinkan seseorang membedakan yang benar dari yang salah dalam semua perbuatan yang disengaja. Menurut al-Ghazali yang termasuk keutamaan al-hikmah ada lima bahagian, yaitu: pemikiran yang baik, pemikiran yang jernih, pendapat yang cemerlang praduga yang benar, dan selalu sadar terhadap sekecil apapun perbuatan dan sehalus apapun kejahatan jiwa.

Dengan demikian, maksud kebijaksanaan di sini adalah kemampuan dan kemauan seseorang menggunakan pemikirannya secara benar untuk memperoleh pengetahuan apa saja sehingga memperoleh pengetahuan rasional. Pengetahuan rasional itu kemudian diaplikasikan 
dalam wujud perbuatan berupa keputusan untuk wajib melaksanakan atau meninggalkan sesuatu. Ini akan tercapai jika berusaha untuk mencapai kebenaran dan menghindar dari segala kesalahan dalam segala hal.

\section{Al-saja'ah atau keberanian}

Pada dasarnya ini adalah sifat pertengahan antara pengecut (al-jubn) dengan nekat (al-tathawwur). Pengecut adalah takut pada sesuatu yang seharusnya tidak perlu ditakuti. Adapun nekat adalah berani terhadap sesuatu yang seharusnya tidak diperlukan sikap ini. Menurut Ibnu Miskawaih yang disebut pemberani itu ditandai setidaknya oleh enam hal: pertama, dalam soal kebaikan ia akan memandang ringan sesuatu yang hakikatnya berat. Kedua, ia sabar terhadap persoalan yang menakutkan. Ketiga, memandang ringan terhadap sesuatu yang umumnya dianggap berat oleh orang lain, sehingga ia rela mati dan memilih sesuatu yang paling utama. Keempat, tidak bersedih terhadap sesuatu yang tidak bisa diraihnya. Kelima, tidak gundah apabila menerima berbagai cobaan. Keenam, kalau ia marah dan mengadakan pembalasan, maka kemarahan dan pembalasannya dilakukan sesuai dengan ukuran, objek dan waktu yang diwajibkan.

Ibnu Miskawaih menyebutnya bahwa sebagaimana al-hikmah, keberanian juga mempunyai cabangcabangnya, dimana ada sembilan cabang keberania, yaitu: jiwa besar, pantang ketakutan, ketenangan, keuletan, murah hati, menahan diri, keperksaan, dan memiliki daya tahan yang kuat atau senang bekerja keras.

Sedangkan al-Ghazali menyebutkan cabang-cabang keberanian yaitu: kemuliaan, pantang ketakutan, keperkasaan, jiwa besar, tahan uji, murah hati, keuletan, tahan marah, tahu diri, dan keramahan.

3. Al-iffah atau menjaga kesucian diri

Keutamaan ketiga ini akan muncul pada diri seseorang bila nafsu dikendalikan oleh pikirannya, di mana ia menyesuaikan pilihan yang benar sehingga bebas, tidak dikuasai dan tidak diperbudak oleh nafsunya. Sifat ini merupakan pertengahan antara rakus (al-syarah) dengan dingin hati (khumud al-syahwat). Yang dimaksud dengan rakus adalah tenggelam dalam kenikmatan dan melampaui batas. Adapun yang dimaksud dengan dingin hati adalah tidak mau berusaha untuk memperoleh kenikmatan yang baik sebatas yang diperlukan, sesuai dengan yang diizinkan syari'at dan akal.

Adapun cabang dari keutamaan sifat al-iffah menurut Ibn Miskawaih adalah: pertama, al-haya' yaitu pengendalian jiwa untuk melakukan perbuatan jelek. Kedua, al-da'ah yaitu ketenangan jiwa ketika nafsu bergejolak. Ketiga, al-shabr yaitu menahan nafsu agar tidak terbuai oleh buruknya kelezatan. Keempat, alsakha' yaitu sikap tengah dalam pemberian. Kelima, al-hurriyah yaitu keutamaan jiwa dalam memperoleh, memberikan dan menolak harta secara benar. Keeman, al-qanaah yaitu sikap sedang dalam makan, minum, dan perhiasan. Ketujuh, ad-damasah yaitu kecenderungan jiwa terhadap yaang baik dan cepat mewujudkannya. 
Kedelapan, al-intizham yaitu kondisi jiwa yang menilai sesuatu secara tepat dan mengaturnya denga cara yang baik. Kesepuluh, al-musalamah yaitu kemampuan diri untuk meninggalkan sesuatu yang tidak baik. Kesebelas, alwaqar ketenangan jiwa ketika tuntunan nafsu mendesak. Keduabelas, al-wara' yaitu kontiniutas/kesinambungan dalam berbuat baik.

\section{Sedangkan}

al-Ghazali

menyatakan cabang-cabang al-iffah lebih banyak lagi dibandingkan Ibn Miskawaih, sebagai berikut: pertama al-haya' yaitu pertengahan antara tidak malu dengan peminis (al-khunusah). Kedua, al-khajal yaitu terlalu malu. Ketiga, al-musahamat yaitu kesediaan melepaskan haknya dengan sukarela. Keempat, al-shabr yaitu kemampuan jiwa melawan nafsu dan menjaganya dari kelezatan yang berakibat buruk. Kelima, al-shakha' yaitu suka memberikan sedekah dan menjauhkan diri dari memperoleh sesuatu yang bukan pada tempatnya. Keenam, husn al-taqdir yaitu seimbang dalam membelanjakan harta. Ketujuh, aldamasah yaitu kondisi al-syahwaniyah yang baik dalam merindukan sesuatu yang sangat diinginkan. Kedelapan, alintizham yaitu kondisi jiwa yang mendorong untuk mengukur diri dalam membelanjakan harta. Kesembilan, hus al-haiah yaitu cinta kepada perhiasan yang tidak sampai tergila-gila. Kesepuluh, al-qana'ah yaitu kemampuan mengatur kehidupan yang baik tanpa cela. Kesebelas, al-hudu yaitu ketenangan jiwa lantaran memperoleh kenikmatan yang baik. Keduabelas, al-wara, yaitu menghiasi jiwa dengan perbuatan yang baik. Ketigabelas, al-thalaqat/lathafat yaitu bergurau yang sopan dan tidak keterlaluan. Keempatbelas al-zarf yaitu pandai menempatkan diri. Kelimabelas, al-musaadat yaitu menghindari perselisihan. Keenambelas, altasakhkhut yaitu pertentangan antara dengki dan gembira atas kedukaan orang lain. Ketujuhbelas, al-inbisath yaitu merasa senang.

\section{Al-adhalah atau keadilan}

Pada prinsipnya keadilan ini merupakan gabungan ketiga keutamaan jiwa yakni al-hikmah, al-saja'ah, aliffah. Dengan demikian, orang tidak akan dikatakan adil kalau tidak tahu cara mengharmonisasikan kebijaksanaan, keberanian, dan kesucian diri. Bertindak sesuai dengan tempatnya, tidak berat sebelah merupakan prinsip dari keadilan itu.

Menurut ibn Miskawaih, keadilan memang diterjemahkan sebagai pertengahan antara al-zulm dan al-inzilam. Al-zulm berarti memperoleh hak milik yang banyak dari sumber dan cara yang tidak semestinya dengan berbuat aniaya. Sedangkan al-inzilam menyerahkan hak milik kepada orang yang tidak semestinya pula teraniaya. Berbeda dengan Ibn Miskawaih, AlGhazali tidak bisa menerima pengertian seperti ini. Menurutnya, keadilan tidak memiliki ekstrim kelebihan dan ekstrim kekurangan. Keadilan hanya mempunyai satu lawan makna yakni ketidakadilan. Ibn Misskawaih membagi keadilan secara umum menjadi tiga macam, yaitu:
1) Keadilan alam (al-adl al- thabi'i/natural justice). Keadilan 
alam ini akan terjadi kalau masingmasing benda alam eksis pada dirinya.

2) Keadilan menurut adat/kebiasaan (al-adl al-wad'i/coventional justiice). Keadilan ini terbagi kepada dua: pertama keadilan umum yaitu disetujui oleh setiap orang. Kedua, keadilan khusus, yaitu hanya disetujui oleh bangsa, daerah, sampai individu, sehingga norma bagi keadilan ini tidak bersifat tetap atau absolut. Adapun ukuran keadilan bagi adat kebiasaan adalah peraturan atau undang-undang yang disepakati.

3) Keadilan Tuhan (al-adl alilahi/divine justice) Keadilan yang khusus diusahakan manusia, ada dalam ketiga keadilan ini. Karena itu, keadilan yang khusus diupayakan manusia tidak dapat dipisahkan dari ketiga keadilan lainnya. Inti dari masing-masing keadilan tersebut adalah bernilai baik selama sisi keharmonisan hubungan dari unsur-unsur yang hakikatnya berbeda.

Selanjutnya Ibn Miskawaih juga menyatakan bahwa keadilan tersebut adalah bernilai baik selama sisi keharmonisan Ibn Miskawaih juga menyatakan bahwa keadilan dalam kaitannya manusia dibagi kepada tiga bagian pula, yaitu: pertama, pembagian harta dan kehormatan; kedua, mua'malah yang disengaja; ketiga, pembagian sesuatu (yang tidak disengaja) yang didalamnya terjadi ketidakadilan.

Berdasarkan uraian penjelasan di atas, dapat dipahami bahwa keadilan akan terwujud apabia telah tercapai kehormonisan pribadi dengan lingkungannya; alam, manusia, dan Tuhan. $^{24}$

\section{Bentuk-bentuk}

Akhlak Mahmudah

Akhlak mahmudah pada prinsipnya merupakan daya jiwa seseorang yang mempengaruhi perbuatannya sehingga menjadi prilaku utama, benar, cinta kebajikan, suka berbuat baik sehingga menjadi watak pribadinya dan mudah baginya melakukan sebuah perbuatan itu tanpa paksaan. ${ }^{25}$ Di antara ciri yang tergolong dalam dalam akhlak mahmudah adalah: ${ }^{26}$

1. Al-Amanah (setia, jujur, dan dapat dipercaya)

2. Al-Sidq (benar dan jujur)

3. Al-Adl (adil)

4. Al-Afw (pemaaf)

5. Al-Alifah (disenangi)

6. Al-Wafa' (menepati janji)

7. Al-Ifafah (memelihara diri)

8. Al-Haya' (malu)

9. Al-Syaja'ah (berani)

10. Al-Quwwah (kuat)

11. Al-Sabr (sabar)

12. Al-Rahman (kasih sayang)

13. Al-Sakha'u (murah hati)

14. At-Ta'awun (penolong/sifat suka tolong menolong)

15. Al-Islah (damai)

16. Al-Ikha' (persaudaraan)

17. Al-Iqtisad (hemat)

${ }^{24}$ Kasmuri Selamat dan Ihsan Sanusi, Akhlak Tasawuf: Upaya Meraih Kehalusan Budi dan Kedekatan Ilahi (Jakarta: Kalam Mulia, 2012), hal. 23-28.

${ }^{25}$ Ibid., hal. 51.

26 Muhammad Aburrahman, Op., Cit., hal. 33 . 
18. Silaturrahmi persaudaraan)

19. Ad-Diyafah (menghormati tamu)

20. At-Tawadhu' (merendah diri)

21. Al-Ihsan (berbuat baik)

22. Al-Khusyu' (menundukkan diri)

23. Al-Muru'ah (berbudi luhur/tinggi)

24. An-Nadhafah (bersih)

25. As-Shalihin (cenderung kepada kebaikan)

26. Al-Qana'ah (merasa cukup dengan apa yang ada)

27. As-Shakinah (tenang dan tentram)

28. Al-Rifq (lemah lembut)

29. Anisatun (bermuka manis)

30. Al-Khair (kebaikan, baik)

31. Al-Hilm (menahan diri dari melakukan maksiat)

32. Al-Tadarru' (merendah diri dari melakukan maksiat)

33. Izzatun Nafs (berjiwa kuat).

Akhlak Mahmudah adalah segala sesuatu yang mendatangkan kebahagiaan dunia dan akhirat serta menyenangkan semua manusia. karena akhlak mahmudah adalah sebagai tuntunan Nabi Muhammad Saw dan kemudian diikuti oleh para sahabat Dan ulama saleh sepanjang masa. ${ }^{27}$

Akhlak mahmudah memiliki hubungan erat dengan iman dan taqwa. Apabila tidak dibarengi akhlak mahmudah maka iman seseorang akan menjadi gersang. Akhlak mahmudah itu seperti yang wujud dalam Alqur'an banyak sekali misalnya, iman, taqwa, amal saleh, amanah, jujur, adil, hikmah, zuhud, suka menolong, suka memeberi maaf, pemurah, dan ramah.

\footnotetext{
${ }^{27}$ Ibid., hal. 34.
}

\section{Keteladanan dan Pembiasaan Guru Pendidikan Agama Islam Berperan dalam Pembinaan Akhlaqul Karimah Siswa}

Pendidikan dalam Islam haruslah berusaha membina atau mengembalikan manusia kepada fitrahnya, yaitu kepada Rubbubiyah Allah sehingga mewujudkan manusia yang berjiwa tauhid, taqwa kepada Allah, rajin beribadah dan beramal shalih, ulil albab, serta berakhlak alkarimah. $^{28}$

Keteladanan merupakan salah satu metode pendidikan yang besar pengaruhnya terhadap keberhasilan proses belajar mengajar, yang dimaksud metode keteladanan di sini yaitu suatu metode pendidikan dengan cara memberikan contoh yang baik kepada para peserta didik, baik dalam ucapan maupun perbuatan. Manusia telah diberi kemampuan untuk meneladani para rasul Allah dalam menjalankan kehidupannya. Di antara rasul Allah yang harus kita contoh adalah nabi Muhammad Saw. Karena beliau telah menunjukkan bahwa pada dirinya terhadap suatu keteladanan yang mencerminkan kandungan Alqur'an secara utuh. ${ }^{29}$

Menurut Al-Ghozali yang di kutib oleh Mahmud keteladanan adalah seseorang yang mempunyai ilmu pengetahuan (alim) yang mengajar ilmunya hanya karena Allah Swt. Yang merupakan salah satu faktor penting

${ }^{28}$ Muchtar, Neri jauhari, Fiqih Pendidikan (Bandung: Remaja Rosdakarya, 2005), hal. 128

${ }_{29}$ Heri Jauhari Muchtar, Fiqih Pendidikan (Bandung: Remaja Rosdakarya, 2008), hal. 224. 
dalam pendidikan, serta besar peranannya dalam rangka menyempurnakan akhlak manusia. ${ }^{30}$ Setiap peserta didik mengidamkan memiliki sosok figur yang dapat dijadikan pedoman dalam kehidupannya. Dalam pendidikan guru adalah salah satu sosok figur yang dapat dijadikan contoh bagi anak didiknya, ketika guru mampu menampilkan keteladanan yang baik tentu saja ha itu akan menjadi salah satu sosok figur yang dapat dijadikan contoh bagi anak didiknya, ketika guru mampu menampilkan keteladanan yanag baik tentu saja hal itu akan menjadi salah satu motivasi bagi anak didik untuk bersikap lebih baik. Persyaratan yang diperlukan untuk menjadi guru itu adalah kepribadian yang layak dan mampu menjalankan tugas. Dengan kata lain, seorang guru selain berilmu, harus dapat dijadikan contoh yang baik (uswah al-hasanah). ${ }^{31}$

Adapun sifat-sifat guru muslim sebagai berikut: 1) kasih sayang pada murid. 2) senang memberi nasehat. 3) senang memberi peringatan. 4) senang melarang murid melakukan hal-hal yang tidak baik. 5) bijak dalam memilih bahan pelajaran yang sesuai dengan lingkungan murid. 6) hormat pada pelajaran lain yang bukan pegangannya. 7) bijak dalam memilih pelajaran yang sesuai dengan taraf kecerdasan murid. 8) mementingkan

\footnotetext{
${ }^{30}$ Mahmud, pemikiran pendidikan Islam (Bandung: CV Pustaka Setia, 2011), hal. 253.

${ }^{31}$ Ibid., hal. 253.
}

berfikir dan berijtihad. 9) jujur dalam keilmuan. 10). Adil. $^{32}$

Fungsi utama guru adalah sebagai teladan bagi anak didiknya. Artinya, bahwa seorang guru harus menjadi contoh dan teladan, membangkitkan motivasi belajar serta mendorong siswa dari belakang. Kemampuan pribadi guru sebagai contoh teladan untuk pembinaan akhlak yang baik mencakup: 1) penampilan sikap yang positif terhadap keseluruhan tugasnya sebagai guru, dan terhadap keseluruhan situasi pendidikan beserta unsurunsurnya. 2) pemahaman, penghayatan, dan penampilan nilai-nilai yang seyogyanya dianut oleh seorang guru. 3) penampilan upaya untuk menjadikan dirinya sebagai panutan dan teladan bagi para siswanya. ${ }^{33}$

Menurut Aristoteles, keutamaan hidup di dapat bukan pertama-tama melalui pengetahuan (nalar), melainkan melalui habitus, yaitu kebiasaan melakukan yang baik. Karena kebiasaan itu menciptakan struktur hidup sehingga memudahkan seseorang untuk bertindak. Melalui habitus, orang tak perlu susah payah bernalar, mengambil jarak atau memberi makna setiap kali hendak bertindak. ${ }^{34}$

Sistem Islam dalam memperbaiki anak kecil adalah bersandar pada dua dasar pokok yaitu pengajaran dan pembiasaan. Maksud pengajaran

${ }^{32}$ Ahmad Tafsir, Ilmu Pendidikan dalam Perspektif Islam (Bandung: PT Remaja Rosdakarya, 2010), hal 48.

33 Bukhari Alma, Guru Profesional: Menguasai Metode dan Terampil Mengajar (Bandung: Alfabeta, 2010), hal. 136-137.

${ }^{34}$ Saptono, Dimensi-dimensi Pendidikan Karakter: Wawasan Srtategi dan Langkah Praktis (Jakarta: Erlangga, 2011), hal. 58. 
(Talqin) di sini ialah pendekatan aspek teoritis dalam upaya memperbaiki anak. Sedangkan yang dimaksud pembiasaan adalah segi praktek nyata dalam proses pembentukan dan persiapannya. Periode anak hendaknya lebih banyak mendapatkan pengajaran dan pembiasaan ketimbang pada usia dan periode lainnya. Suatu kemestian bagi para pendidik, bapak, ibu, dan para guru adalah menekankan pengajaran dan pembiasaan anak sejak dini untuk melakukan kebaikan. ${ }^{35}$ Sebagai awal dalam proses pendidikan pembiasaan merupakan cara yang sangat efektif dalam menanamkan nilai-nilai moral ke dalam jiwa anak.

\section{KESIMPULAN}

UU No. 14 tahun 2005 Tentang Guru dan Dosen menegaskan bahwa "Dalam melaksanakan tugas keprofesionalan, guru berkewajiban merencanakan pembelajaran, melaksanakan proses pembelajaran yang bermutu, serta menilai dan mengevalusai hasil pembelajaran serta meningkatkan dan mengembangkan kualifikasi akademik dan kompetensi secara berkelanjutan sejalan dengan perkembangan ilmu pengetahuan, teknologi, dan seni".

Menurut Peraturan Menteri Pendidikan Nasional Republik Indonesia Nomor 16 Tahun 2007 Tentang Standar Kualifikasi Akademik dan Kompetensi Guru, adapun macammacam kompetensi yang harus dimiliki oleh tenaga guru antara lain yaitu:

35 Abdullah Nashih Ulwan, Kaidahkaidah Dasar (Bandung: PT Rosdakarya, 1992), hal. 60. kompetensi pedagogik, kompetensi kepribadian, kompetensi sosial, dan kompetensi profesional. Guru dalam Islam harus memiliki kompetensi/kemampuan sebagai berikut: zuhud, kebersihan guru, ikhlas, pemaaf, seorang guru merupakan seorang bapak/ibu, seorang guru harus mengetahui tabiat murid, dan seorang guru harus menguasai mata pelajaran.

Akhlak mahmudah pada prinsipnya merupakan daya jiwa seseorang yang mempengaruhi perbuatannya sehingga menjadi prilaku utama, benar, cinta kebajikan, suka berbuat baik sehingga menjadi watak pribadinya dan mudah baginya melakukan sebuah perbuatan itu tanpa paksaan.

Fungsi utama guru adalah sebagai teladan bagi anak didiknya. Artinya, bahwa seorang guru harus menjadi contoh dan teladan, membangkitkan motivasi belajar serta mendorong siswa dari belakang. Kemampuan pribadi guru sebagai contoh teladan untuk pembinaan akhlak yang baik mencakup: 1) penampilan sikap yang positif terhadap keseluruhan tugasnya sebagai guru, dan terhadap keseluruhan situasi pendidikan beserta unsurunsurnya. 2) pemahaman, penghayatan, dan penampilan nilai-nilai yang seyogyanya dianut oleh seorang guru. 3) penampilan upaya untuk menjadikan dirinya sebagai panutan dan teladan bagi para siswanya.

Pendidikan dalam Islam haruslah berusaha membina atau mengembalikan manusia kepada fitrahnya, yaitu kepada Rubbubiyah 
Allah sehingga mewujudkan manusia yang berjiwa tauhid, taqwa kepada Allah, rajin beribadah dan beramal shalih, ulil albab, serta berakhlak alkarimah

\section{DAFTAR PUSTAKA}

Abdul Karim Zaidan. Ushul adDa'wah. Bagdad: Jam'iyyah alAmani. 1976.

Abdullah Nashih Ulwan. Kaidahkaidah Dasar. Bandung: PT Rosdakarya. 1992.

Abu Hamid Muhammad al-Ghazali. Ihya Ulum ad-Din. Beirut: Dar alFikr. 1989.

Ahmad Rohani dan Abu Ahmad. Pengelolaan Pengajaran. Jakarta: Rineka Cipta. 1996.

Ahmad Tafsir. Ilmu Pendidikan dalam Perspektif Islam. Bandung: PT Remaja Rosdakarya. 2010.

Anonim. Al-Qur'an Terjemah. Jakarta: Akbar As-Samad. 2014.

Asef Umar Fakhruddin. Menjadi Guru Favorit. Yogyakarta: DIVA Press. 2009.

Beni Ahmad Saebani \& Abdul Hamid. Ilmu Akhlak. Bandung: CV Pustaka Setia. 2010.

Bukhari Alma. Guru Profesional: Menguasai Metode dan Terampil Mengajar. Bandung: Alfabeta. 2010.

Erwin Yuda Prahara. Materi Pendidikan Agama Islam. Ponorogo: STAIN Ponorogo Press. 2009.

FKI LIM. Gerbang Pesantren: Pengantar Memahami Ajaran Ahlussunnah wal Jama'ah.

Heri Jauhari Muchtar. Fiqih Pendidikan. Bandung: Remaja Rosdakarya. 2008.
Imam Musbikin. Guru Yang Menakjubkan. Yogyakarta: Buku Biru. 2010.

Kasmuri Selamat dan Ihsan Sanusi. Akhlak Tasawuf: Upaya Meraih Kehalusan Budi dan Kedekatan Ilahi. Jakarta: Kalam Mulia. 2012.

Kediri: Bidang Penelitian dan Pengembangan LIM PP Lirboyo. 2010.

M. Athiyah Al-Abrasyi. Dasar Dasar Pokok Pendidikan Islam. Jakarta: Bulan Bintang, 1993.

Mahmud. Pemikiran Pendidikan Islam. Bandung: CV Pustaka Setia. 2011.

Muchtar Neri jauhari. Fiqih Pendidikan. Bandung: PT Remaja Rosdakarya. 2005.

Muhammad Abdurrahman. Akhlak: Menjadi Seorang Muslim Berkhlak Mulia. Jakarta: Rajawali Press. 2016.

Muhibbin Syah. Psikologi Pendidikan suatu Pendekatan Baru. Bandung: Remaja Rosdakarya, 1996.

Mukhtar dan Iskandar. Orientasi Baru Supervisi Pendidikan. Jakarta: Gaung Persada. 2009.

Ngainun Naim. Menjadi Guru Inspiratif: Membudayakan dan Mengubah Jalan Hidup Siswa. Yogyakarta: Pustaka Pelajar. 2009.

Qody Iyad Ibn Musa Al Yahsubi. Keagungan Kekasih Allah Muhammad SAW. Jakarta: PT. Raja Grafindo Persada. 2002.

Saptono. Dimensi-dimensi Pendidikan Karakter: Wawasan Srtategi dan Langkah Praktis. Jakarta: Erlangga. 2011.

Sukarji \& Umiarso. Manajemen dalam Pendidikan Islam. Jakarta: Mitra Wacana Media. 2014. 
UU No. 14 Tahun 2005 Tentang Guru dan Dosen Bab IV Pasal 20

Zakiah Daradjat. Ilmu Pendidikan Islam. Jakarta: Bumi Aksara.1992.

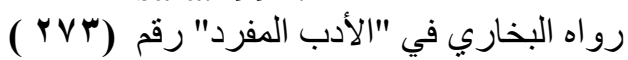
https://eprints.uns.ac.id/263/1/1703123 11201011381.pdf. 